\title{
Erratum to: Nonlinear dynamic systems identification based on dynamic wavelet neural units
}

\author{
L. Saad Saoud $\cdot$ A. Khellaf
}

Published online: 1 February 2011

(C) Springer-Verlag London Limited 2011

Erratum to: Neural Comput \& Applic (2010)

19:997-1002

DOI 10.1007/s00521-010-0438-9

This article has been removed due to unclear circumstances during the publication process.

The online version of the original article can be found under doi:10.1007/s00521-010-0438-9.

L. Saad Saoud ( $\square)$

Department of Physics, Faculty of Sciences,

University M'hamed Bougara, Boumerdès, Algeria

e-mail: saadsaoudl@yahoo.fr

A. Khellaf

Department of Electronic, Faculty of Engineering,

University Ferhat Abbas, Sétif, Algeria 